\title{
THE EVOLUTION OF CONSULTANCY FIRMS IN THE MANAGEMENT OF NON-REIMBURSABLE FUNDS DURING THE 2020 PANDEMIC
}

\author{
Gabriela Victoria ȚEPUȘ ${ }^{a^{*}}$ \\ ${ }^{a}$ Babeş-Bolyai University, Romania
}

DOI: $10.24818 / \mathrm{IMC} / 2020 / 05.11$

\begin{abstract}
The crisis generated by Covid-19 affects the world not only from a health perspective, but also from a socio-economic one. While facing an unmatched situation, governments have reacted differently in order to bolster their economies. This article deals with the activity of consultancy firms from the non-reimbursable funds domain and means to adapt to the current situation, but it also touches on the support established by the Romanian Government for enterprises and economic recovery. The key questions this article aims to answer are the following: how is the government planning to invigorate the economy and what immediate effects should antrepreneurs expect? The main question of this research remains: Has the context of the pandemic represented a disadvantage or a springboard for new services coming from consultancy firms in the management of nonreimbursable funds?
\end{abstract}

KEYWORDS: COVID-19, economic support measures, European and national funds, management consulting services.

\section{INTRODUCTION}

The novel coronavirus (COVID-19) started at the end of 2019 from the Chinese region of Wuhan (WHO Timeline - COVID-19, 2020), spreading until May 2020 to 2012 countries and territories (Coronavirus Update (Live): Worldometer, 2020). Europe and EU states have been affected by the pandemic starting with February, and the authorities' responses have been, with few exceptions, quite similar. The most common measures were: the establishment of the state of emergency, social distancing, prohibiting events and public gatherings, closing up schools and fobidding some economic activities. In Romania, preventive measures were generally more severe compared to the rest of the continent. In addition to all the problems and damages caused by the new coronavirus regarding health, there is also an incommensurable number of economic risks and losses. Without comparing the effects of the health crisis and the effects of an eventual economic crisis, the present study aims to analyze the management of consultancy firms in the non-reimbursable funds domain in the critical period of a pandemic from three perspectives: ethical, stressing the role of the consultant, marketing and restructuring in emergency situations. These aspects will be analyzed in parallel with the series of measures introduced by the Government of Romania during the establishment of the state of emergency and later for supporting the economy, respectively for restarting the activity or the subsequent economic invigoration.

The economic recovery plan sets out a massive state support for almost every economic domain and invokes investments in infrasctucture, agriculture, health or education worth tens of billion of Lei or Euros. The magnitude of changes and the increase in competition that explores the field of

\footnotetext{
* Corresponding author. E-mail address: gabrielatepus@gmail.com
} 
management and, in this case, of consultancy for non-reimbursable funds, are the main elements which lead to a greater accent on implementing and undertaking new marketing and work strategies for successful projects. Companies look for new opportunities for growth, cost-effectiveness and survival in times of quick and extremely competitive changes. This article has two major objectives. The first objective is presentation and analysis of the measures taken by the Romanian Government during the pandemic crisis. The second objective is to analysis of consultancy firms in the management of non-reimbursable funds, handling the activity during a crisis and maintaining social responsibility towards customers.

\section{LITERATURE REVIEW}

\subsection{Ethical responsibilities of Management Consultants towards clients}

Social responsibility represents a great challenge that the community and companies are facing due to the pressure stemming from their responsibility in front of legal, ethical, moral or any other expectations. It is self-evident that it adds value and leads the management structure to another level. What's more, consultancy firms have to pay attention not only to internal factors for the wellbeing of employees, but also to external ones in their relationship with customers and other collaborators so as to reach their objectives. From here arises one of the questions to be addressed in this study: Is the financial responsibility able to bring financial benefits and to maintain safety and honesty between the customer and the consultant?

Ethics distinguish between wrong and wise approaches, which means that it is a social value just like fairness, honesty, truthfulness or others which control the behavior and actions of companies towards their employees and customers (Fassin et al, 2011). Social responsibility and marketing strategies were tackled together because social responsibility can be used as a strategic marketing instrument through which a society can acquire notoriety, access on the market, an exemplary image, ensuring a very good reputation that can subsequently attract new customers (Dobrea, 2006). Studies show that there is a special link between ethics and performance, with the majority of literature indicating towards how extremely beneficial ethics can be on long-term, but not as efficient on short-term. Trust plays an especially important role at the workplace, and its contribution can be seen in efficient work relationships, good practices of the company and the method of information delivery. Honesty is important for companies, but it is not easily accomplished as long as there is a disparity between honesty and personal interest (Morsing \& Schultz, 2006). In the field of management consultancy, a key factor towards success should be represented by the attention given to customers' trust in the provided services. It is strongly believed that consultancy firms have an ever-growing presence in modern business. Their role is sometimes self-explanatory, but at the same time there is a series of approaches of consultants' roles in innovative activities. Anna Canato and Antonio Giangreco have structured the efficiency and the role of management consultants in four categories with the following perspectives (Canato Anna and Giangrevo Antonio, 2011). 
Table 1. Typology of the role of consultants in innovative activities

\begin{tabular}{|l|l|l|l|l|}
\hline \multicolumn{5}{|c|}{ Perspectives } \\
\hline $\begin{array}{l}\text { Main } \\
\text { purpose }\end{array}$ & $\begin{array}{l}\text { Information sources } \\
\text { Provide customers with } \\
\text { specific information } \\
\text { about market or } \\
\text { technological trends }\end{array}$ & $\begin{array}{l}\text { Standard setters } \\
\text { Propose and diffuse } \\
\text { the same solution for } \\
\text { different costumers } \\
\text { brokers }\end{array}$ & $\begin{array}{l}\text { Help customers } \\
\text { develop original } \\
\text { solutions }\end{array}$ & $\begin{array}{l}\text { Knowledge } \\
\text { integrator }\end{array}$ \\
\hline $\begin{array}{l}\text { Source of } \\
\text { legitimation } \\
\text { solutions }\end{array}$ & $\begin{array}{l}\text { Greater expertise and } \\
\text { established experience } \\
\text { in a given industry }\end{array}$ & Reputation & $\begin{array}{l}\text { Experience in } \\
\text { different } \\
\text { industries }\end{array}$ & $\begin{array}{l}\text { Previous } \\
\text { experience with } \\
\text { the same solution }\end{array}$ \\
\hline $\begin{array}{l}\text { Locus of } \\
\text { experience }\end{array}$ & $\begin{array}{l}\text { Better availability of } \\
\text { information. Multiple } \\
\text { contacts with firms and } \\
\text { institutions of the } \\
\text { industry }\end{array}$ & $\begin{array}{l}\text { Brand; development } \\
\text { of new standards }\end{array}$ & $\begin{array}{l}\text { Brokering } \\
\text { mechanisms } \\
\text { (e.g., contacts, } \\
\text { use of } \\
\text { knowledge } \\
\text { databases) }\end{array}$ & $\begin{array}{l}\text { Specific expertise } \\
\text { of consultants }\end{array}$ \\
\hline
\end{tabular}

Source: Canato Anna and Giangrevo Antonio, 2011

The ethical responsibility a consultant has in the management of non-reimbursable funds is heading towards the client and making correct, specific and safe information available to him. In a field in which procedures and governance are constantly changing, it is extremely difficult to keep an honest appearance, thus contributing to the insecurity a client can feel towards the system (Clark 1995; Edvardsson 1990).

\subsection{Economic invigoration support measures in Romania between March-August 2020}

The health and economic crisis determined by the Covid-19 global pandemic has shown the vulnerabilities of Romania due to the developmental model heretofore promoted. With a view to surpass the negative effects of the pandemic and to increase economic resilience, the Government has assigned considerable resources to intervene against Covid-19 and to support the economic activity. The first confirmed case of conoravirus on national territory was announced on February 26, preceding the first legislative action from March 6, the GSTSCBIC Decision number 6 (Grupul de suport tehnico-știinţific privind gestionarea bolilor înalt contagioase pe teritoriul României). Starting with March 16, Romania enters the state of emergency for a period of 30 days according to the Decree of the President of Romania regarding the establishment of the state of emergency on the Romanian territory, followed by an additional 30 days. Measures of utmost urgency with gradual applicability have imposed the temporary closure of some restaurants, hotels, cafés, clubs, casinos, association headquarters and other public spaces (Decret al Președintelui României nr. 195/16). These sectors were not the only ones affected by the context of the COVID-19 pandemic, and the first solutions proposed by the Government of Romania to support the economy surfaced on March 21, when Ordinance no. 30/2020 was published, dealing with the establishment of social protection measures in the context of the epidemiological situation determined by the spread of the SARSCoV-2, which was later simplified through OUG no. 32/2020. Thus, the Government has enacted the conditions for claiming technical unmeployment and regulated the online deposit of necessary documents for social benefits during the state of emergency (Ordonanța de urgenţă 32 din 
26.03.2020). Rebuilding Romania, as was designated the National Ivestment and Economic Recovery Plan, comprised three great categories of economic measures and policies, namely: Fiscal and budgetary support policies in the context of Covid-19, Programmes for supporting and protecting jobs affected by the Covid-19 crisis and Support grants for restarting enterprises, work capital and investments. The first two facilities will not be analyzed in the present study as they are not directly subject to research. Thus, the grant facilities will be presented because they directly and deliberately influence the demand for consultancy offers (Guvernul României, 2020, https://gov.ro/fisiere/programe_fisiere/Planul_Na\%C8\%9Bional_de_Investi\%C8\%9Bii_\%C8\%99i_ Relansare_Economic\%C4\%83.pdf).

Table 2. Support grants to restart enterprises, work capital and investments

\begin{tabular}{|c|c|c|c|c|c|c|}
\hline Nr. & $\begin{array}{c}\text { Grant } \\
\text { designation }\end{array}$ & $\begin{array}{l}\text { Value and } \\
\text { intensity of } \\
\text { financing }\end{array}$ & Aid type & Allotment & $\begin{array}{c}\text { Estimated } \\
\text { number of } \\
\text { beneficiaries }\end{array}$ & Observations \\
\hline 1. & $\begin{array}{l}\text { Work capital } \\
\text { microgrant }\end{array}$ & $\begin{array}{l}\text { EUR 2.000, } \\
\text { Intensitate100\% }\end{array}$ & $\begin{array}{l}\text { COVID } \\
\text { temporary } \\
\text { de minimis }\end{array}$ & $\begin{array}{l}\text { EUR } \\
100.000 .000\end{array}$ & 50.000 & $\begin{array}{l}\text { SMEs with sole } \\
\text { associate/administrator, } \\
\text { without individual labor } \\
\text { contract (SMEs without } \\
\text { employees); registered } \\
\text { sole traders which } \\
\text { undertake activities in the } \\
\text { arts and entertainment } \\
\text { field; registered sole } \\
\text { traders with activities in } \\
\text { the health domain, if they } \\
\text { were directly involved in } \\
\text { the transportation, } \\
\text { equipment, evaluation, } \\
\text { diagnosis and treatment } \\
\text { of COVID-19 patients. }\end{array}$ \\
\hline 2. & $\begin{array}{l}\text { Aid schema for } \\
\text { commerce } \\
\text { activities and } \\
\text { services affected } \\
\text { by Covid-19 }\end{array}$ & N/A & $\begin{array}{l}\text { COVID } \\
\text { temporary } \\
\text { de minimis }\end{array}$ & $\begin{array}{l}\text { Lei } \\
160.000 .000\end{array}$ & $\begin{array}{l}2.000 \\
\text { merchants }\end{array}$ & $\begin{array}{l}\text { For rent payment during } \\
\text { crisis, for commerce and } \\
\text { services. }\end{array}$ \\
\hline 3. & $\begin{array}{l}\text { Work capital to } \\
\text { restart economic } \\
\text { activities for } \\
\text { SMEs }\end{array}$ & $\begin{array}{l}\text { EUR } 5.000- \\
125.000 \\
15 \%\end{array}$ & $\begin{array}{l}\text { COVID } \\
\text { temporary } \\
\text { de minimis }\end{array}$ & $\begin{array}{l}\text { EUR } \\
350.000 .000\end{array}$ & $\begin{array}{l}90.000 \\
100.000\end{array}$ & $\begin{array}{l}\text { For } 4 \text { affected sectors: } \\
\text { HoReCa, transport, travel } \\
\text { agencies, event planning }\end{array}$ \\
\hline 4. & $\begin{array}{l}\text { Grants for } \\
\text { investments and } \\
\text { the conversion } \\
\text { of SMEs }\end{array}$ & $\begin{array}{l}\text { EUR } 50.000- \\
200.000 \\
\text { Maximum } 85 \% \\
\text { intensity }\end{array}$ & $\begin{array}{l}\text { COVID } \\
\text { temporary } \\
\text { de minimis }\end{array}$ & $\begin{array}{l}\text { EUR } \\
550.000 .000\end{array}$ & $\begin{array}{l}2.750 \\
3.100\end{array}$ & $\begin{array}{l}\text { For most domains, } \\
\text { unconditioned by the } \\
\text { level of affection, } \\
\text { including Bucureşti-Ilfov }\end{array}$ \\
\hline 5. & $\begin{array}{l}\text { Grants for } \\
\text { investments in } \\
\text { renewable } \\
\text { energy for } \\
\text { SMEs }\end{array}$ & $\begin{array}{l}\text { EUR } 30.000 \\
100 \% \text { intensity }\end{array}$ & $\begin{array}{l}\text { Environment } \\
\text { fund and the } \\
\text { MEEMA } \\
\text { Budgetary }\end{array}$ & $\begin{array}{l}\text { EUR } \\
200.000 .000\end{array}$ & 7.000 & $\begin{array}{l}\text { Grants for installing } \\
\text { photovoltaic panels, } \\
\text { maximum } 27 \mathrm{KW} \text {, but } \\
\text { also for the acquisition } \\
\text { and installation of } \\
\text { charging stations for } \\
\text { electric cars. }\end{array}$ \\
\hline 6. & $\begin{array}{l}\text { POR } 2.2- \\
\text { national call }\end{array}$ & $\begin{array}{l}\text { EUR } 2.000 .000 \\
-6.000 .000 \\
\text { Maximum } 70 \% \\
\text { intensity }\end{array}$ & State aid & $\begin{array}{l}\text { EUR } \\
550.000 .000\end{array}$ & $150-180$ & \\
\hline
\end{tabular}




\begin{tabular}{|c|c|c|c|c|c|c|}
\hline Nr. & $\begin{array}{c}\text { Grant } \\
\text { designation }\end{array}$ & $\begin{array}{c}\text { Value and } \\
\text { intensity of } \\
\text { financing }\end{array}$ & Aid type & Allotment & $\begin{array}{c}\text { Estimated } \\
\text { number of } \\
\text { beneficiaries }\end{array}$ & Observations \\
\hline 7. & $\begin{array}{l}\text { Grants for start- } \\
\text { ups and students } \\
\text { in innovative } \\
\text { and competitive } \\
\text { domains }\end{array}$ & $\begin{array}{l}\text { EUR } 40.000- \\
100.000\end{array}$ & $\begin{array}{l}\text { Minimis } \\
\text { standard }\end{array}$ & $\begin{array}{l}\text { EUR } \\
150.000 .000\end{array}$ & $\begin{array}{l}1.300 \\
1.5000\end{array}$ & $\begin{array}{l}\text { POCU Innotech Student, } \\
\text { Universities will apply } \\
\text { through partnerships and } \\
\text { will offer grants to the } \\
\text { target group (students) }\end{array}$ \\
\hline 8. & $\begin{array}{l}\text { Grants for the } \\
\text { digitalization of } \\
\text { SMEs }\end{array}$ & $\begin{array}{l}\text { EUR } 30.000- \\
100.000\end{array}$ & $\begin{array}{l}\text { COVID } \\
\text { temporary } \\
\text { de minimis }\end{array}$ & $\begin{array}{l}\text { EUR } \\
150.000 .000\end{array}$ & $\begin{array}{l}1.300 \\
1.5000\end{array}$ & \\
\hline 9. & $\begin{array}{l}\text { Star-Tech } \\
\text { Innovation } \\
\text { (successor of } \\
\text { Start-up Nation) }\end{array}$ & $\begin{array}{l}\text { EUR } 42.000 \\
100 \% \text { intensity }\end{array}$ & $\begin{array}{l}\text { De minimis } \\
\text { standard }\end{array}$ & $\begin{array}{l}\text { EUR } \\
294.000 .000\end{array}$ & 7.000 & $\begin{array}{l}\text { SuN successor, focused } \\
\text { on technology }\end{array}$ \\
\hline 10. & $\begin{array}{l}\text { Financing } \\
\text { programmes } \\
\text { for the digital } \\
\text { education } \\
\text { of SMEs } \\
\text { employees }\end{array}$ & $\begin{array}{l}\text { EUR } 30.000- \\
100.000\end{array}$ & $\begin{array}{l}\text { FSE } \\
(\mathrm{POCU})\end{array}$ & $\begin{array}{l}\text { EUR } \\
30.000 .000\end{array}$ & $420-440$ & - \\
\hline 11. & $\begin{array}{l}\text { Grants for the } \\
\text { acquisition } \\
\text { of irrigation } \\
\text { equipment }\end{array}$ & EUR 6.000 & $\begin{array}{l}\text { COVID } \\
\text { temporary } \\
\text { de minimis }\end{array}$ & $\begin{array}{l}\text { EUR } \\
48.000 .000\end{array}$ & 8.000 & - \\
\hline 12. & $\begin{array}{l}\text { Financing grants } \\
\text { for rural } \\
\text { entrepreneurship }\end{array}$ & $\begin{array}{l}\text { EUR } 40.000- \\
100.000\end{array}$ & $\begin{array}{l}\text { FSE } \\
(\mathrm{POCU})\end{array}$ & $\begin{array}{l}\text { EUR } \\
200.000 .000\end{array}$ & $\begin{array}{l}2.800 \\
2.880\end{array}$ & $\begin{array}{l}\text { For processing } \\
\text { agricultural products }\end{array}$ \\
\hline 13. & $\begin{array}{l}\text { Providing } \\
\text { young farmers } \\
\text { with agricultural } \\
\text { lands from the } \\
\text { state }\end{array}$ & - & FEADR & $\begin{array}{l}\text { EUR } \\
42.000 .000\end{array}$ & - & - \\
\hline 14. & $\begin{array}{l}\text { State aid schema } \\
\text { for new } \\
\text { investments } \\
\text { (greenfield) }\end{array}$ & $\begin{array}{l}\text { EUR } \\
37.500 .000\end{array}$ & State aid & $\begin{array}{l}1,5 \text { billion } \\
\text { Lei } \\
\text { annually }\end{array}$ & 40 & - \\
\hline 15. & $\begin{array}{l}\text { State aid schema } \\
\text { to support } \\
\text { investments } \\
\text { which promote } \\
\text { regional } \\
\text { development }\end{array}$ & $\begin{array}{l}\text { EUR } \\
37.500 .000\end{array}$ & State aid & $\begin{array}{l}450.000 .000 \\
\text { Lei } \\
\text { annually }\end{array}$ & 12 & - \\
\hline 16. & $\begin{array}{l}\text { Financing grants } \\
\text { for rural } \\
\text { entrepreneurship }\end{array}$ & $\begin{array}{l}\text { EUR } 40.000- \\
100.000\end{array}$ & $\begin{array}{l}\text { FSE } \\
(\mathrm{POCU})\end{array}$ & $\begin{array}{l}\text { EUR } \\
200.000 .000\end{array}$ & $\begin{array}{l}2.800 \\
2.880\end{array}$ & $\begin{array}{l}\text { For processing } \\
\text { agricultural products }\end{array}$ \\
\hline
\end{tabular}

Source: Own editing, based on the literature reviewed

As seen in Table 2, the economic recovery plan has an ambitious proposal of over EUR 100 billion and is to be financed by the state budget and European funds. The programme proposed by the Government has a main goal of ensuring the convergence with European economies, so as the Gross Domestic Product per capita to parity by standard purchase will reach $87 \%$ of the EU27 average, on the dawn of 2025 (Guvernul României, 2020, 
https://gov.ro/fisiere/programe_fisiere/Planul_Na\%C8\%9Bional_de_Investi\%C8\%9Bii_\%C8\%99i_ Relansare_Economic\%C4\%83.pdf).

In the last few years, the GDP per capita has evolved compared to the average purchasing power as follows: $2016-59 \%, 2017-63 \%, 2018-65 \%$, $2019-69 \%$. By means of these indicators, we can speculate that in 6 years Romania should increase by 18 points, which would not necessarily represent an unreachable objective, seeing that in the abovementioned years the GDP has been growing by 10 points. At the moment, it is clear that Romania, despite its recent years' economic growth, remains one of the poorest countries in the EU, humbly surpassing Greece, Bulgaria and Croatia in 2019, GDP-wise (Eurostat Press Office, 2020).

The manifestation of the Covid-19 pandemic in 2020 has led to an uncertain global macroeconomic scenario, as there still is a mixture of hardly quantifiable factors that inhibit economic growth, in a background of applying public health safety measures. The effects of the pandemic were less obvious in the Romanian economy in the first quarter of 2020, but started to develop in March. Thus, compared to the first quarter of 2020, the GDP of the second quarter of 2020 decreased with $12,3 \%$. Compared to the same quarter in 2019 , the GDP has recorded a drop of $10,5 \%$ in the second quarter of 2020, both grossly and on the seasonally adjusted series (INS, 2020, https://insse.ro/cms/sites/default/files/com_presa/com_pdf/pib_tr2r2020.pdf).

\section{RESEARCH METHOLOGY, ANALYSIS AND RESULTS}

In order to respond to the research question approaches were undertaken from multiple perspectives, taking into account the sensitive context in which we might be heading towards an economic collapse. The research question is the following: Has the context of the pandemic represented a disadvantage or a springboard for new services coming from consultancy firms in the management of non-reimbursable funds? Thus, the analysis was accomplished through the following lens: demand for services, methods of promoting and delivering information through websites, request for the Certificate for Emergency Situations.

The first aspect to be analyzed is the Certificate for Emergency Situations, a document that offers certain facilities to those companies whose activity was affected in the context of the pandemic. Taking into account the Decree from the President of Romania regarding the establishment of the emergency situation, the first two military prdinances of 2020 and the Government's emergency ordinance no. 30/2020 for the modification and completion of some normative acts, as well as for the establishment of some measures in domain of social protection in the context of the epidemiological situation determined by the spread of SARS-CoV-2 and the Government's emergency ordinance $\mathrm{nr}$. 29/2020 regarding some economic and fiscal-budgetary measures, the idea of the certificate for emergency situations was introduced through Ordinance no. 791 of 24.03.2020 on granting certificates for emergency situations of the Ministry of Economy, Energy and Business Environment to economic operators whose activity is affected in the context of SARS-CoV-2 pandemic. There are two types of certificates: blue and yellow. The blue certificate can be requested by economic enterprises whose activity was totally or partially interrupted as a result of decisions taken by the competent public authorities, while the yellow one is granted, based on an affidavit, to legal entities which have recorded a loss of at least $25 \%$ of revenue or income in March or April 2020 compared to the average revenues of January-February 2020 (Modificări la emiterea Certificatelor de Situaţie de Urgență în favoarea operatorilor economici, 2020). The method of obtaining these certificates is simplified, the applicants uploading the identification data and the affidavit by which they confirm the veracity of the request on the platform http://prevenire.gov.ro. An electronic signature is needed for registration and those of accountants are also accepted. A few minutes after submitting the documents, the certificates are issued exclusively online, at no costs. At the same time, it should be noted that these emergency certificates were not limited to sectors of activity, even if the form initially concerned only the following: transport, tourism, HoReCa, event 
planning, advertising, primary education and related activities, the garment industry, footwear and leather goods and general services. The facilities that can benefit the entreprises which obtain emergency situations certificates are: the postponement of utility payments (electricity, natural gas, water, phone and internet services), as well as rent, the possibility of invoking force majeure against them only after the renegotiation of contracts and the postponement for a period of 9 months of existing loans introduced by OUG 37 from 30.03.2020 regarding the grant of facilities for loans given by credit institutions and non-banking financial institutions to a certain category of debtors. Taking this into account and the fact that the CSU indicates to a greater or lesser extent those firms who were indeed affected in this period, for this study the following indicators were analyzed from the online list - The list of firms in Romania with complete information („Lista firmelor din România cu informații complete"- a website where an access fee is requested from members https://www.listafirme.ro/).

Table 3. CSU indicators

\begin{tabular}{|l|l|l|l|}
\hline Analyzed indicator & Total number & Percentage & \multicolumn{1}{|c|}{ Observations } \\
\hline $\begin{array}{l}\text { No. Consultancy } \\
\text { firms (7022) to have } \\
\text { submitted their } \\
\text { review for 2019 }\end{array}$ & 21492 & $100 \%$ & $\begin{array}{l}\text { The firms were filtered by their main area of } \\
\text { activity. It is important to note that each } \\
\text { company in Romania can receive income from } \\
\text { a generous list of fields. The society has only } \\
\text { one main area of activity and all the other } \\
\text { domains from which the turnover is generated } \\
\text { must fall under the CAEN authorized codes. } \\
\text { Companies must engage in activities under } \\
\text { domain 7022 in order to undertake consultancy } \\
\text { services in management including } \\
\text { management services for non-reimbursable } \\
\text { funds. }\end{array}$ \\
\hline $\begin{array}{l}\text { No. Consultancy } \\
\text { firms (7022) to have } \\
\text { obtained BLUE CSU }\end{array}$ & 225 & $1,047 \%$ & $\begin{array}{l}\text { For judicial persons who have recorded a } \\
\text { decrease of at least 25\% in cash collection or } \\
\text { revenues in March or April 2020 compared to } \\
\text { the average earnings from January-February } \\
2020\end{array}$ \\
\hline $\begin{array}{l}\text { No. Consultancy } \\
\text { firms (7022) to have } \\
\text { obtained YELLOW } \\
\text { CSU }\end{array}$ & 324 & $1,508 \%$ & $\begin{array}{l}\text { For the judicial persons whose activity was } \\
\text { partially or completely interrupted as a } \\
\text { consequence of the decisions issued by the } \\
\text { competent public authorities }\end{array}$ \\
\hline
\end{tabular}

Source: Own editing, based on the literature reviewed

Taking into account the provided indicators, the national-level situation is as follows.

Table 4. Obtaining CSU structured on development regions

$\begin{array}{cccccccccc}\begin{array}{c}\text { Development } \\ \text { region }\end{array} & \begin{array}{c}\text { NORTH- } \\ \text { EAST }\end{array} & \begin{array}{c}\text { SOUTH- } \\ \text { EAST }\end{array} & \begin{array}{c}\text { SOUTH } \\ \text { MUNTENIA }\end{array} & \begin{array}{c}\text { SOUTH- } \\ \text { WEST } \\ \text { OLTENIA }\end{array} & \text { WEST } & \begin{array}{c}\text { NORTH- } \\ \text { WEST }\end{array} & \text { CENTER } & \begin{array}{c}\text { BUCURESTI- } \\ \text { ILFOV }\end{array} & \text { TOTAL } \\ \text { Yellow CSU } & 24 & 16 & 21 & 15 & 30 & 48 & 18 & 152 & 324 \\ \text { Blue CSU } & 19 & 14 & 17 & 8 & 17 & 25 & 29 & 96 & 225 \\ \text { Total CSU } & 43 & 30 & 38 & 23 & 47 & 73 & 47 & 248 & 549\end{array}$

Source: Own editing, based on the literature reviewed 


\section{The distribution of CSU requests by consultancy firms}

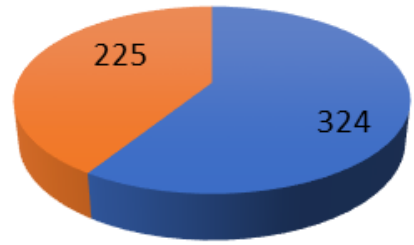

- CSU Galben $\quad$ CSU Albastru

Figure 1. The distribution of CSU requests by consultancy firms Source: Own editing, based on the literature reviewed

\section{The situation of consultancy firms which have requested CSU on development regions}

\begin{tabular}{|c|c|c|c|c|c|c|c|c|}
\hline \multirow{3}{*}{$\begin{array}{l}300 \\
208 \\
108 \\
58\end{array}$} & \multicolumn{4}{|c|}{ CSU Galben } & \multicolumn{3}{|c|}{ Total CSU } & \multirow[b]{2}{*}{152248} \\
\hline & 241943 & 161430 & 211738 & 15823 & 301747 & $4825^{73}$ & 182947 & \\
\hline & $\begin{array}{c}\text { NORD- } \\
\text { EST }\end{array}$ & SUD-EST & $\begin{array}{c}\text { SUD } \\
\text { MUNTE } \\
\text { NIA }\end{array}$ & $\begin{array}{c}\text { SUD- } \\
\text { VEST } \\
\text { OLTENIA }\end{array}$ & VEST & $\begin{array}{c}\text { NORD- } \\
\text { VEST }\end{array}$ & CENTRU & $\begin{array}{c}\text { BUCURE } \\
\text { STI- } \\
\text { ILFOV }\end{array}$ \\
\hline - CSU Galben & 24 & 16 & 21 & 15 & 30 & 48 & 18 & 152 \\
\hline - CSU Albastru & 19 & 14 & 17 & 8 & 17 & 25 & 29 & 96 \\
\hline - Total CSU & 43 & 30 & 38 & 23 & 47 & 73 & 47 & 248 \\
\hline
\end{tabular}

Figure 2. The situation of consultancy firms which have requested CSU, by development regions

Source: Own editing, based on the literature reviewed

As seen from the total number of firms in Romania whose main area of activity is consultancy services in management, only 2,55\% of them have requested CSU in April-August 2020. Fom here stems the question whether only such a small percentage of economic operators are affected according to the definition, directly or indirectly, or if many entrepreneurs did not request the document because they did not need it or did not see its purpose. Out of all the regions, it seems that București - Ilfov is the most affected and its number of CSU requests is slightly smaller than all the regions combined.

Another important aspect in the context of the pandemic, which seems to have brought a substantial incentive to the domain of consultancy, is the economic recovery plan previously presented. An ambitious plan through which consultancy firms will enlarge their area of application and the list of interested customers. For this study, the websites for promoting services of 26 companies from the field of non-reimbursable funds were analyzed in order to verify the trasparency of services, package sales methods and the applied marketing strategies. 


\section{Table 5. Analyzed websites of consultancy firms}

\begin{tabular}{|c|c|c|c|c|c|}
\hline $\begin{array}{l}\text { Nr. } \\
\text { crt. }\end{array}$ & $\begin{array}{c}\text { CDNSULTANCY } \\
\text { FIRMS }\end{array}$ & WEBSITE & $\begin{array}{c}\text { PRDVIDES } \\
\text { INFDRMATIDN } \\
\text { ABDUT } \\
\text { PACKAGE I MLD }\end{array}$ & $\begin{array}{c}\text { PARTIAL } \\
\text { INFORMATIIN }\end{array}$ & $\begin{array}{c}\text { INFORMATION MINIMAL } \\
\text { CRITERIA FOR } \\
\text { PARTILIPATION }\end{array}$ \\
\hline 1 & $\begin{array}{l}\text { FABRILA DE } \\
\text { CDNSULTANTA } \\
\text { SRL }\end{array}$ & $\frac{\text { https://www.fabricad }}{\text { econsultanta.com/ }}$ & $\begin{array}{l}\text { Promotes the } \\
\text { package }\end{array}$ & $\begin{array}{l}\text { Dnly the maximum } \\
\text { value of financing }\end{array}$ & \\
\hline 2 & $\begin{array}{c}\text { MDRADD } \\
\text { BUSINESS SRL }\end{array}$ & $\frac{\text { https://moradaconsul }}{\underline{\text { ting.ra } /}}$ & $\begin{array}{l}\text { Promotes the } \\
\text { package }\end{array}$ & & \\
\hline 3 & $\begin{array}{l}\text { SC CENTRU DE } \\
\text { ELABDRARE } \\
\text { PRDIECTE } \\
\text { UNIDNALE SRL }\end{array}$ & https://cepu.ro/ & $\begin{array}{l}\text { Does not } \\
\text { promote the } \\
\text { package }\end{array}$ & & \\
\hline 4 & $\begin{array}{c}\text { REIDEN } \\
\text { BUSINESS } \\
\text { CDNSULTING } \\
\text { SRL }\end{array}$ & https://reiden.ro/ & $\begin{array}{l}\text { Promotes the } \\
\text { package }\end{array}$ & & $\begin{array}{l}\text { Shows only the } \\
\text { minimal eligibility } \\
\text { criteria and the CAEN } \\
\text { codes list }\end{array}$ \\
\hline
\end{tabular}
INFDRMATION CRITERIA
MAXIMUM SCORE

Shows on the site all the information related to this financing line, including eligibility and selection criteria, including CAEN codes list.

Shows on the site all the information related to this financing line, including eligibility and selection criteria, including CAEN codes list.
Dnly the maximum

G LONG WAY SRL $\frac{\text { http://www.long- }}{\underline{\text { way.eu/ }}} \quad \begin{gathered}\text { Promotes the } \\ \text { package }\end{gathered}$

ODAS GLOBAL

7 CONSULTING

SRL

ACTIV BUSINESS
ADVISOR SRL

REG

g

RCG
CONSULTING
GRDUP

10 AREAFORU SRL https://area4u.ro/

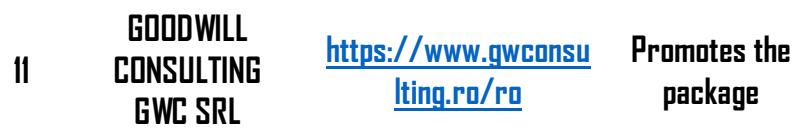

value of financing, principal domains, main expenditure

Does not promote the package Does not promote the package Does not promote the package

Promotes the package

Only the maximum value of financing, minimal contribution

Shows eligibility criteria, eligible expenditure, value of financing. Shows the minimal participation criteria and eligible expenditure. 


\section{2}

SNCMARITEXR S

RL

https://antreprevision. rol

MARG \&

13

ASSOCIATES

EURDPEAN

FUNDS SRL

https://meuropeanfunds

$$
\text { ra/ }
$$

Promotes the package

Does not

14 MAGNA SRL $\frac{\text { http://www.magna.ru }}{\underline{I}}$

15 ARIA UNITED SRL https://ariaunited.com/ promate the package Does not promote the package
I6 CONSULTANTA http://succes- Promotes the DE SUCCES SRL $\quad \underline{\text { consult.ro/ }}$ package
ROMCDM INVEST https://rameom.ro/
SRL
Does not promate the package

18 ACDNSULTING https://acansulting.ro/

Promotes the

Dnly the maximum package

Does not promate the package

19 CONSULTING https://www.incepta.ro/

SRL

KELSD

20

CONSULTING https://kelsa.ra/

PARTENER

21 CAMYRE SRL https://camyre.ro/

Promotes the

Promotes the package

value of financing, principal domains,

Shows minimal participation criteria and eligible expenditure

$$
\begin{aligned}
& \text { Shows minimal } \\
& \text { participation } \\
& \text { criteria, eligible } \\
& \text { expenditure, and } \\
& \text { eligible principal } \\
& \text { domains }
\end{aligned}
$$

Only the maximum value of the project

Shows minimal
participation criteria
and eligible
expenditure
Shows minimal
participation
criteria, eligible
expenditure, and
eligible principal
domains
Shows minimal
participation
criteria, eligible
expenditure, and
eligible principal
domains

Shows on the site all the information related to this financing line, including eligibility and selection criteria, including CAEN codes list. 
25 SRL
SIENA BB CONS $\frac{\text { https://sienaconsulting. }}{\mathrm{ra} / \mathrm{P}}$

\section{Promotes the package}

\section{Shows minimal participation criteria, eligible expenditure, and eligible principal domains \\ 26

$\begin{array}{llc}\text { CHRDMA } & & \text { Promates the } \\ \text { CDNSULTING } & \text { https://chrama.ra/ } & \text { package }\end{array}$

Shows on the site all the information related to this financing line, including eligibility and selection criteria, including CAEN codes list.

Source: Own editing, based on the literature reviewed

We should note that the 26 firms were chosen from different regions, in the SME category, and the important criteria was owning a promoting website. As seen above, only 9 of the firms do not promote the 1 billion package. The proposed programmes were presented in this article with the purpose of highlighting the plethora of programmes the Government will analyze in the upcoming period. Compared to the period before the pandemic, we can certainly say that these priorities are more ambitious and will lead to a bigger demand for consultancy services. Throughout the course of the last year, three national programmes were expected but never launched. Two of the important support programmes are not on their first call, and to exemplify the fact that not only the demand will increase, but so will the competition, some features of these programmes will be outlined. The first example is the Regional Operational Programme priority axis 2.2., a programme for enterprises with market activity, with a non-reimbursable value between EUR 200.000 and EUR 1.000 .000 and a maximum of 70\% intensity, launched for certain regions: North East, South East, South Muntenia, South West Oltenia. Therefore, in the North East region the allotment was of Lei 152, 102 million, and the value of submitted projects was of Lei 3.290, 18 million, with a 10 times bigger coverage for the call, namely of 1.097,40\% (ADR Nord-Est, 2020, http://www.inforegionordest.ro/situatieproiecte). The situation remains the same with Southern regions, such as the closed call for May in South Muntenia reaching the following values: alloted value Lei 177,34 million, value of submitted projects Lei 3.288,80 million, coverage of 1.041,75\% (ADR Sud Muntenia, 2020, https://regio.adrmuntenia.ro/situatia-proiectelor-depuse/static/1026). In the Western region the situation is more, so to say, balanced than the rest of the regions, with a coverage of only 120,14\% (ADR Vest, 2020, https://adrvest.ro/por-2014-2020/stadiul-implementarii/). The second example, this time for newcomer firms recently founded, is the Start-Up Nation programme, which has notoriety on the market, launching for the third time along with the economic recovery plan. The last session was considered a real success for the authorities but a disappointment for the applicants. The programme was competitive, with a 100\% intensity, a value of EUR 42.000 and 10.000 beneficiaries. 33.514 projects were submitted, of which 32.152 companies received 100 points. Thus, the tiebreaker criteria had an extremely important role, first criteria being the number of employees, the second the share of technological equipment, and the next criteria the date and hour of submission. The line of projects accepted for financing was laid out to 4 employees in the context that each of them must be kept 2 years after the implementing phase of the project is over. The completion of the submission session revealed data that the applicants were probably not expecting: projects with more than 4 employees - 5.984, and with 4 employees - 11.018 (Ministerul pentru Mediul de Afaceri, Comerţ şi Antreprenoriat, 2019, http://www.imm.gov.ro/ro/2019/02/15/listaaplicantilor-start-up-nation-in-ordinea-atribuita-de-registrul-unic-electronic/). The programme will be relaunched based on innovation, and the number of projects that will be accepted for financing falls by 3.000 than the last session. 
The previous chapter dealt with the subject of social responsibility and the uncertainty of the field which hinders the ethics and performance process. The tough competition for some programmes, the impossibility to anticipate the total number of applicants and the additional criteria the companies must meet lead to some trust issues in the domain. This is exactly why the method of promoting the package proposed by the Government was analyzed, namely the grants already launched through OUG 130/2020 regarding some measures for non-reimbursable external financial support, related to the Competition Operational Programme 2014-2020 in the context of the Covid19 crisis. Analizing the data from table 5, we can note that the information delivered by means of one's own website is correct, only the strategy differs. Four out of the analyzed firms have chosen to show the criteria for the maximum score, and eight of them present only the minimal criteria for submitting a project, revealing the importance some firms put in the development phase of projects with real chances of being approved.

\section{DISCUSSION AND CONCLUSIONS}

This article was headed towards achieving two main goals. First of them was related to the presentation and analysis of measures taken by the Government of Romania during the pandemic, from the point of view of economic recovery, influencing the demand for consultancy services. A second matter of interest was the analysis of consultancy firms in the management of nonreimbursable funds, handling the activity during a crisis and maintaining social responsibility towards customers.

The Government's attention has shifted in this period towards the provision of financing programmes for work capital in the domains directly affected by the ordinances issued at the beginning of the pandemic, investments in state guarantees, grants and aid schemes for new investments in order to resume or convert economic activities. Therefore, the short-term priority of the Government is to ensure the necessary work capital to enterprises affected by Covid-19 as a consequence of temporary closure of activity, reducing the demand for consumption and supply chain disruptions. Since the presentation of the economic recovery plan, $1^{\text {st }}$ of July, we have seen emerging only the ordinance regulating the eligibility conditions for three out of sixteen proposals. It is necessary to apply these programmes as fast as possible, so that the enterprises won't wait for some programmes that might not even cover half their needs. Societies' need for liquidities is quite high if we review the current situation of the IMM Invest programme which aimed to offer firms access to work and investment capital through guaranteeing up to $90 \%$ of credits by the Ministry of Public Finances through the National Fund of Credit Guarantee for Small and Medium Enterprises and the subsidy of interest-rates and banking expenditures (ex. administration fees, risk fees, guarantee premium). On August $26^{\text {th }}$, the number of registered enterprises reached 67.523, of which approved by the bank:14.256 and rejected by the bank: 26.455. Societies' facility of having fees paid for by the state comprises only the year 2020, and, at present, less than $21 \%$ of firms benefit from this facility.

After analyzing consultancy firms and the services they provide in this period, we can state that they are experiencing prosperous times with plenty of ideas for economic support. The effiency of activities has increased due to the introduction of digitalization and de-bureaucratisation methods in administration and economy, as well as the widespread recognition of digitally-signed documents, which are necessary for some programmes and can be requested online, thus shortening the waiting time. The work in this domain ca be easily transferred online and the consulting process can be supported by applications, similar to the process of projects' submission or implementation. Not only the target market has directly benefitted from some of these facilities, but also the companies in this domain. As seen in the analysis of the Certificate for Emergency Situations, we can note that an extremely low number of consultancy firms have requested the issuance of the certificate, maybe because they did not have decreases in revenue or cash collection, their activity was not 
interrupted, or they did not think the document can be useful. To conclude, taking into account all the aspects subject to this research, we can certainly claim that consultancy firms have been going through a favorable period that allows them to develop their services. The Government's proposal regarding a recovery program has represented a source of growth for the demand in consultancy services. Economic actors have experienced critical situations during the pandemic, but their attention seems to have shifted toward state aid due to a lack of capital and the closing of sectors. The digital attainment facilities for some documents represented a decrease in bureaucracy and shortened the time dedicated to funding requests in the consultancy domain. Increasing notoriety, trust and safety, alongside constant adaptation, are essential elements in the consultancy domain, as the consultants must own correct and relevant information and be able to prepare successful strategies without altering their customers'activity. Obviously, the method by which the information is delivered to the suited public is an important aspect, which is why the analyzed websites proved that the information, be it minimal for some programmes, is correct but not sufficient for a project's success, as the strategies undertaken by firms based on the programme and any antecedents can be game changers.

\section{REFERENCES}

ADR Nord-Est (2020). Situație depuneri proiecte REGIO Nord-Est la 31.07.2020, Retrieved August 25, 2020, form http://www.inforegionordest.ro/situatie-proiecte.

ADR Sud Muntenia (2020). Situaţia proiectelor depuse în cadrul POR 2014-2020 la nivelul regiunii Sud Muntenia - 25 august 2020, Retrieved August 25, 2020, from https://regio.adrmuntenia.ro/situatia-proiectelor-depuse/static/1026.

ADR Vest (2020). Stadiul apelurilor de proiecte lansate în cadrul POR 2014-2020, Retrieved August 25, from https://adrvest.ro/por-2014-2020/stadiul-implementarii/

Anna, C. \& Antonio, G. (2011). Gurus or Wizards? A review of the role of management consultants. European Management Review, Vol. 8, 231-244, DOI: 10.1111/j.17404762.2011.01021.x.

Decret al Președintelui României nr. 195/16 (n.d.), In Anaf, Retrieved August 11, 2020, from http://legislatie.just.ro/Public/DetaliiDocumentAfis/223831.

Edvardsson, B. (1990). Management Consulting: Towards a Successful Relationship, International Journal of Service Industry Management, 1 (3), 4-19, doi: 10.1108/09564239010136902.

Eurostat Press Office (2020). First estimates of Purchasing Power Parities for 2019, Eurostat Newsrelease, $\quad$ Retrieved August 4, 2020, from https:/ec.europa.eu/eurostat/documents/2995521/11005802/2-18062020-AP-EN.pdf/2469350fca14-6809-9a72-a4814893dcf2.

Fassin, Y., Van Rossem, A. \& Buelens, M. (2011). Small-business owner-managers'perceptions of business ethics and CSR-related concepts. Journal of Business ethics, 98(3), 425-453. doi: 10.1007/s10551-010-0586-y.

Guvernul României (2020). Planul național de investiții și relansare economică, Retrieved August 1, 2020 ,

https://gov.ro/fisiere/programe_fisiere/Planul_Na\%C8\%9Bional_de_Investi\%C8\%9B

ii_\%C8\%99i_Relansare_Economic\%C4\%83.pdf.

Institutul Naţional de Statistică (2020). Comparativ cu trimestrul I 2020, produsul intern brut în trimestrul II 2020 a fost, în termeni reali, mai mic cu 12,3\%, 14 August 2020, Retrieved August 17, 2020, from https://insse.ro/cms/sites/default/files/com_presa/com_pdf/pib_tr2r2020.pdf.

Ministerul pentru Mediul de Afaceri, Comerţ şi Antreprenoriat (2020). Lista aplicantilor start-up nation in ordinea atribuita de registrul unic electronic, Retrieved August 25, 2020, from http://www.imm.gov.ro/ro/2019/02/15/lista-aplicantilor-start-up-nation-in-ordinea-atribuita-deregistrul-unic-electronic/. 
Morsing, M. \& Schultz, M. (2006). Corporate social responsibility communication: Stakeholder information, response and involvement strategies, Business ethics: Aeuropean review, 15(4), 323-338. doi: 10.1111/j.1467-8608.2006.00460.x.

Ordinul nr. 791 din 24.03.2020 (n.d.), In Portal Legislativ, Retrieved August 25, 2020, from http://legislatie.just.ro/Public/DetaliiDocument/224399.

Ordonanţa de urgenţă a Guvernului nr. 130/2020 (n.d.), In Portal Legislativ, Retrieved August 12, 2020, from http://legislatie.just.ro/Public/DetaliiDocument/228699.

Ordonanţa de urgenţă a Guvernului nr. 30/2020 (n.d.), In Portal Legislativ, Retrieved August 11, 2020, from http://legislatie.just.ro/Public/DetaliiDocument/224272.

Ordonanța de Urgență a Guvernului nr. 32/2020 (n.d.), In Anaf, Retrieved August 11, 2020, from https://static.anaf.ro/static/10/Anaf/legislatie/OUG_32_2020.pdf.

Ordonanța de Urgență a Guvernului nr. 37/2020 (n.d.), In Portal Legislativ, Retrieved August 25, 2020, from http://legislatie.just.ro/Public/DetaliiDocument/224489.

Răzvan, C., D. (2020). Managementul organizațiilor și responsabilitatea socială corporativă, Administrație și management public, 7/2006, Retrieved August 4, 2020, from http://ramp.ase.ro/_data/files/articole/7_12.pdf.

WHO Timeline - COVID-19 (n.d.). Retrieved August 19, 2020, from https://www.who.int 